\title{
THE ROLE OF JOB SATISFACTION IN MEDIATING THE EFFECT OF LEADERSHIP ON EMPLOYEE PERFORMANCE
}

\author{
Saiful Amin \\ Higher Education of Economic Mandala \\ Email: saiful@stie-mandala.ac.id
}

\begin{abstract}
This study aims to determine the role of job satisfaction in mediating the relationship between leadership and employee performance. This research was conducted at Dira park Ambulu Jember. The population in this study were all employees of Dira park Ambulu Jember, totaling 186 employees. The sample used was 46 respondents chosen by random sampling. Data analysis method uses path analysis. To determine the role of job satisfaction in mediating the relationship between leadership and employee performance was analyzed using the sobel test. The results of this study indicate that leadership has a significant effect on job satisfaction and employee performance. The results of this study also showed that job satisfaction did not significantly influence employee performance. In the results of this study also explained that the variable job satisfaction cannot mediate the effect of the relationship between leadership on the employee performance of Amba Jember Park.
\end{abstract}

Keyword: Leadership, Work Satisfaction, Employee Performance

\section{INTRODUCTION}

The success of a company in achieving its goals is strongly influenced by the human resources contained in the company. Human resources are a very important element in determining the success of a company. This can be seen from the results of employee performance to support company goals. An employee's performance is an individual thing, because each employee has a different level of ability in carrying out their duties. The management can measure the employee's performance based on the performance of each employee. Seeing the increasingly fierce development and competition of the company, the company's performance is demanded not only to be maintained, but factors that need to be considered in an effort to improve company performance are needed.

One important factor that affects employee performance is leadership. Good leadership is the key in management which has an important role in the strategy for the survival of a company. A good leader is a leader who is able to plan, allocate, move and be fair to all his employees so that employees feel satisfied with their work that in the end they can improve the quality of work.

Another factor that can support employee performance is job satisfaction. 
Job satisfaction is an important condition that must be owned by every employee who works, where people are able to interact with the work environment and they will work passionately and earnestly so that the contribution to the achievement of company goals will increase, More and more aspects of the work in accordance with the wishes and value systems adopted by individuals, the higher the level of satisfaction obtained. Job satisfaction in this study is a positive or negative attitude of employees towards work situations and conditions related to the benefits they receive.

In this study, researchers will see a portrait of leadership and job satisfaction in influencing employee performance at Dira park Ambulu Jember. Dira park Ambulu Jember is one of the tourist destinations in Jember district. The current condition of the employees of Dira park Ambulu Jember is still not optimal. This can be seen from the managerial role in creating a working atmosphere for all employees. Several employees mentioned that the leadership of Dira park Ambulu Jember did not prioritize professionalism in measuring performance levels. Employee recruitment is always done in private and usually new employees who are accepted have a kinship with other employees, this will certainly affect job satisfaction and company performance.

Some research on the effect of leadership on employee performance through job satisfaction has been done by previous researchers. (Rusady \& Suprayitno, 2011) in his research stated that leadership has no effect on employee performance either directly or mediated by job satisfaction. This happens because employees are accustomed to the leadership that has been applied by the company so that employees are not aware of the influence of leadership that causes increased employee performance. Another study states that leadership style, partially positive and significant effect on employee job satisfaction, (Gusti \& Adnyani, 2018).
This result shows the important role of leadership style in increasing job satisfaction. This result is supported by the findings of research conducted by (Depitra \& Soegoto, 2018) that leadership has a significant positive effect on job satisfaction. Some research on the effect of job satisfaction on performance has been done by previous researchers. (Martha \& Simanungkalit, 2013) states that job satisfaction has a positive and significant effect on employee performance. This result is supported by the findings of research conducted by (Anke Priyono, 2012) which also states that job satisfaction has a positive and significant effect on employee performance. In addition, (Prasetya \& Dewi, 2019) also states that job satisfaction has a positive and significant effect on employee performance. Based on some of the results of the study above shows that there are some differences in research findings related to the influence of leadership on job satisfaction and employee performance. This study aims to determine the role of job satisfaction in mediating the relationship between leadership and employee performance

\section{RESEARCH METHODS}

This research is a quantitative research. Quantitative research is research that requires a lot of use of numbers, ranging from data collection, interpretation of the data, as well as the appearance of the results (Sugiyono, 2014). This study consists of three variables, namely leadership (X), Job Satisfaction (Z) and Employee Performance (Y). Leadership as the ability to influence or encourage a person or group so that people work voluntarily to achieve certain goals or objectives in certain situations. This variable is measured using indicators of decision making ability, communication ability, ability to control subordinates, responsibility and ability to control emotionally. Job satisfaction is a positive attitude from the workforce including feelings and behavior towards work 
through the assessment of one job as a sense of respect in achieving one of the important values of the work. Job satisfaction is measured by indicators of work, wages, promotions, supervisors and coworkers. Employee performance is how much the employees contribute to the company including the quantity of output, the quality of output the period of time, workplace attendance and cooperative attitude. Employee performance is measured by indicators of quality, quantity, timeliness, effectiveness, independence and work commitment.

The population in this study were 186 employees of Dira Park Ambulu. The sample in this study amounted to 46 respondents chosen from the total population multiplied by $25 \%$. The sampling technique uses simple random sampling that is sampling and the population is carried out randomly without regard to strata in the population that way is done when a population member is considered homogeneous (Sugiyono, 2011)

Data analysis method in this study uses path analysis. Path analysis is an extension of multiple linear regression analysis, or path analysis is the use of regression analysis to estimate causal relationships between variables (casual models) that have been predetermined based on theory. Before conducting the analysis the data path was tested to determine the level of validity and reliability. Then the classic assumption test is performed which includes the normality test, the multicollinearity test and the heterokedasticity test. To find out the direct effect of the independent variables on the intervening and dependent variables, a ttest was performed, while to find out the role of job satisfaction in mediating the relationship between leadership variables on employee performance was carried out with the sobel test. (Ferdinand, n.d.)

\section{RESULTS ANALYSIS}

\section{Data Validity Test}

Validity test is used to measure the validity of a questionnaire. An indicator is said to be valid if the r-calculated value is greater than the r-table value. other than that an indicator is said to be valid if it has a significance value below 0.05 . The results of the data validity test can be seen in the following Table 1.

Table 1. Data Validity Test Results

\begin{tabular}{cccccc}
\hline Variabel & Item & $\begin{array}{c}\text { r- } \\
\text { table }\end{array}$ & $\begin{array}{c}\text { r- } \\
\text { value }\end{array}$ & Sig & Note \\
\hline & X.1 & 0,2907 & 0,887 & 0,000 & valid \\
Leadership & X.2 & 0,2907 & 0,918 & 0,000 & valid \\
(X) & X.3 & 0,2907 & 0,865 & 0,000 & valid \\
& X.4 & 0,2907 & 0,904 & 0,000 & valid \\
& X.5 & 0,2907 & 0,889 & 0,000 & valid \\
Work & Z.1 & 0,2907 & 0,882 & 0,000 & valid \\
Satisfaction & Z.3 & 0,2907 & 0,723 & 0,000 & valid \\
(Z) & Z.4 & 0,2907 & 0,881 & 0,000 & valid \\
& Z.5 & 0,2907 & 0,860 & 0,000 & valid \\
& Y.1 & 0,2907 & 0,883 & 0,000 & valid \\
Employee & Y.2 & 0,2907 & 0,910 & 0,000 & valid \\
Performance & Y.3 & 0,2907 & 0,924 & 0,000 & valid \\
(Y) & Y.4 & 0,2907 & 0,900 & 0,000 & valid \\
& Y.5 & 0,2907 & 0,920 & 0,000 & valid \\
& Y.6 & 0,2907 & 0,866 & 0,000 & valid \\
\hline Source: Primary
\end{tabular}

Based on Table 1 above, it can be seen the results of validity testing show that all statements relating to the variables of Leadership (X), Job satisfaction (Z), and employee performance (Y) obtain $r$ counts greater than $r$ tables and the significance value is less than 0.05 so it can be interpreted that all statements used in this research questionnaire are valid and can be used as instruments for collecting research data.

\section{Data Reliability Test}

Reliability test is a tool to measure a questionnaire which is an indicator of a variable or construct. A questionnaire is said to be reliable or reliable if someone's answer to the question is consistent from time to time. The results of the data reliability test can be seen in the following Table 2: 
Table 2. Data Reliability Test Results

\begin{tabular}{|c|c|c|c|}
\hline Variable & $\begin{array}{c}\text { Cronbach's } \\
\text { Alpha }\end{array}$ & $\begin{array}{c}\text { Standart } \\
\text { Reliability }\end{array}$ & Note \\
\hline $\begin{array}{c}\text { Leadership } \\
\text { (X) } \\
\text { Work }\end{array}$ & 0,927 & 0,60 & Reliable \\
\hline $\begin{array}{l}\text { Satisfaction } \\
\text { (Z) }\end{array}$ & 0,852 & 0,60 & Reliable \\
\hline $\begin{array}{c}\text { Employee } \\
\text { Performance } \\
\text { (Y) }\end{array}$ & 0,951 & 0,60 & Reliable \\
\hline
\end{tabular}

Based on Table 2 above the reliability test results show that all leadership variables (X), job satisfaction (Z), and employee performance (Y) obtain a Cronbach's alpha value above 0.60 and the value is relatively consistent so that it can be interpreted that the instruments used in this study reliable.

\section{Path Analysis}

Path analysis is an extension of multiple linear regression analysis, or path analysis is the use of regression analysis to estimate causal relationships between variables (casual models) that have been predetermined based on theory. This analysis aims to determine the direct and indirect effects, simulatively or partially of some exegenal variables on endogenous variables. The path analysis results in this study are explained as follows:

\section{Path Analysis Substructure 1}

Path analysis in sub-structure 1 aims to examine the relationship of influence between leadership variables $(\mathrm{X})$ on job satisfaction (Y). The results of the path analysis in substructure 1 can be seen in the following Table 3 .

Table 3. Results of Path Analysis 1

\begin{tabular}{|c|c|c|c|c|c|c|}
\hline \multirow[t]{2}{*}{ Model } & & \multicolumn{2}{|c|}{ Unstandardized Coefficients } & \multirow{2}{*}{$\begin{array}{c}\begin{array}{c}\text { Standardized } \\
\text { Coefficients }\end{array} \\
\text { Beta } \\
\end{array}$} & \multirow[t]{2}{*}{$\mathbf{t}$} & \multirow[t]{2}{*}{ Sig. } \\
\hline & & $\mathbf{B}$ & Std. Error & & & \\
\hline & (Constant) & 7,709 & 1,881 & & 4,098 & ,000 \\
\hline & $\mathrm{X}$ &, 614 & 090 & ,718 & 6,843 & ,000 \\
\hline a. Depe & dent Variable: Z & & & & & \\
\hline
\end{tabular}

Based on Table 3 above it can be seen that the t-value for the leadership variable is 6.843 , greater than t-table (1.678). In addition the significance value indicates 0,000 less than 0.05. Thus it can be said that the leadership variable has a significant effect on job satisfaction of Dira Ambulu Jember employees. This means that the better the leadership style carried out by Dira Ambulu Jember management, the more job satisfaction of Dira Ambulu Jember employees will be.

\section{Path Analysis Substructure 2}

Path analysis in sub-structure 2 aims to examine the relationship between the influence of leadership variables $(\mathrm{X})$ and job satisfaction $(\mathrm{Z})$ on job satisfaction $(\mathrm{Y})$. The results of the path analysis in substructure 2 can be seen in the following Table 4.

Table 4. Path Analysis Results 2

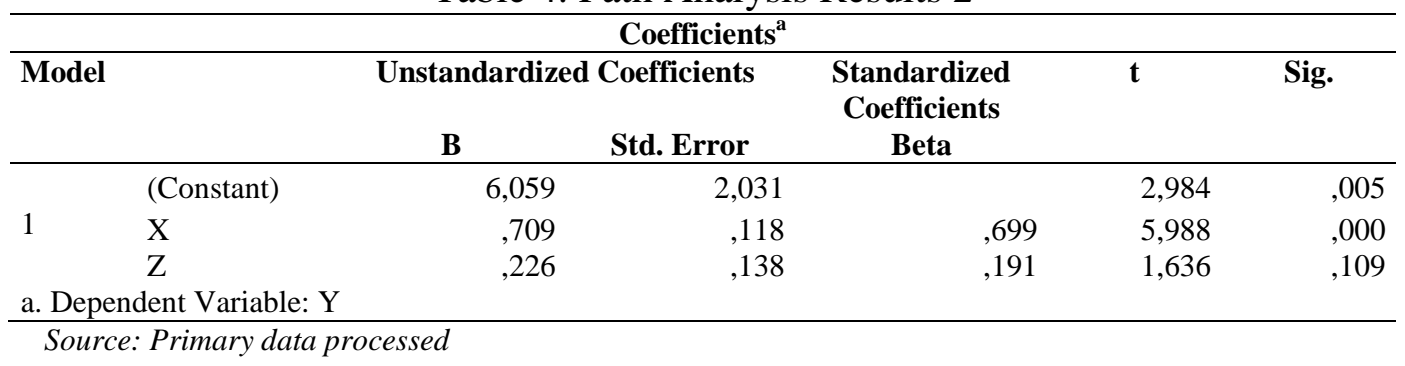


Based on Table 4 above it can be seen that the $t$-count value for the leadership variable is 5.988 greater than ttable (1.678) with a significance value of 0.00 less than 0.05 . Thus it can be said that the leadership variable has a significant effect on the employee performance of Dira Ambulu Jember. This means that the better the leadership style undertaken by the management of Dira Ambulu Jember, the more it will improve the performance of the employees of Dira Ambulu Jember. In addition, the t-value for the variable job satisfaction is 1.636 smaller than t-table (1.678) with a significance value of 0.109 greater than 0.05 . Thus it can be said that the variable job satisfaction does not significantly influence the performance of employees of Dira Ambulu Jember.

\section{Path Diagram}

Based on the results of the calculation of the paths in substructure 1 and substructure 2 that have been described above, a path diagram can be formed which can be seen in Figure 1 below.

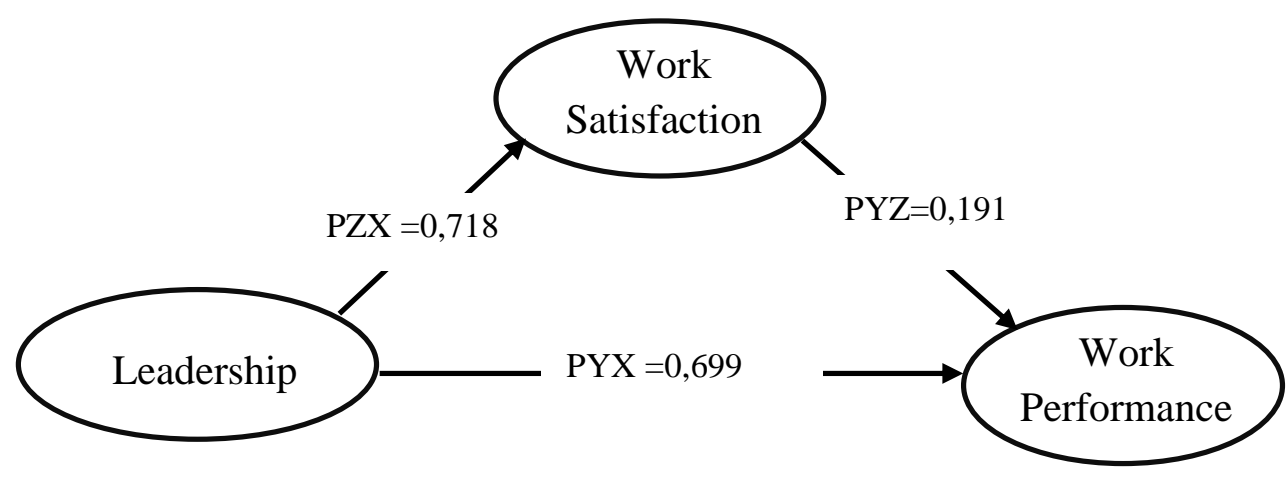

Figure 1. Path Diagram

\section{Sobel Test}

Mediation hypothesis testing can be done by a procedure developed by Sobel (1982) and is known as the Sobel Test (Sobel test). Sobel test is done by testing the strength of the indirect effect of the independent variable $(\mathrm{X})$ on the dependent variable (Y) through the intervening variable $(\mathrm{Z})$. Sobel test will produce a $\mathrm{t}-$ value and standard error of the indirect effect coefficient (SAB) that is used to detect the role of mediating variables or not. The sobel test formula is as follows:

$\mathrm{Sab}=\sqrt{b^{2} S a^{2}+a^{2} S a^{2}+S a^{2} S b^{2}}$

Based on the results of the sobel test with the Sobel Test Calculator for the Significance of Mediation tool it is known that the sobel test yields a 1.363 figure with a probability value of 0.086 . These results indicate that the variable job satisfaction cannot mediate the relationship between leadership variables on employee performance in Dira Ambulu Jember.

\section{INTERPRETATION}

In testing the hypothesis explains that leadership affects job satisfaction. This means that the leadership applied by the management of Dira Ambulu Jember is very good so that it can affect employee job satisfaction. These findings have proven that effective leadership depends on a solid managerial foundation seen from the indicators above, a good leader in leading employees will create job satisfaction for employees of Dira Ambulu Jember. Leadership is measured through five indicators namely the ability to make decisions, the ability to communicate, the ability to control subordinates, responsibilities, the ability to control emotionally. Based on the field findings or the results of the questionnaire, the majority of respondents stated strongly 
agree with the Dira leadership system where the leader is able to control subordinates effectively with the aim of the company's long-term interests and employees also agree that the leader has responsibilities to both employees and his work. So it can be concluded that most employees strongly agree with the leadership system and therefore the leadership variable applied to Dira is very good so that it can have an effect on job satisfaction. The results of this study support the findings of research conducted by (Gusti \& Adnyani, 2018) which states that leadership influences job satisfaction. This study also supports the findings of a study conducted by (Anke Priyono, 2012) and (Martha \& Simanungkalit, 2013) judge who stated that leadership influences job satisfaction.

Hypothesis testing also explains that leadership influences performance. This means that the leadership system at Dira Ambulu in Jember can create improvements in employee performance. Leadership is measured by indicators of decision making, communication, controlling subordinates, responsibility and emotional control. These results indicate that the leadership of Dira park Ambulu has emotional maturity in the sense of being able to control emotions that are stable or calm in overcoming various problems and not in a hurry to make a decision, not easily influenced by information that is not yet clear. Besides that the ambulu dira park leadership is also able to behave communicatively in the sense that the ambulu park leadership can speak well and be easily understood, so that people who receive messages are happy and quickly carry out what is conveyed by the leadership. In the decision making and supervision system carried out by the leadership of Dira park Ambulu, it is quite good, so that managerial performance can run according to the objectives expected by the company. The results of this study support the findings of research conducted by (Jamaludin, 2017) which states that leadership influences employee performance. This result also supports the findings of research conducted by(Rusady \& Suprayitno, 2011), (Mohd.Kurniawan DP1, 2018) and (Prasetya \& Dewi, 2019) which states that leadership influences employee performance.

In testing the hypothesis explains that job satisfaction does not affect employee performance. This means that satisfaction obtained by Dira employees is not able to encourage employees to achieve optimal performance. Job satisfaction is measured by indicators of work, wages, promotions, supervisors and coworkers. Job satisfaction is the attitude (positive) of the workforce towards his work, which arises based on an assessment of the work situation. The assessment can be done on one of his work. Assessment is done as a sense of respect in achieving one of the important values at work. Satisfied employees prefer job situation than dissatisfied employees. These results indicate that employees who get satisfaction with the returns from their work may not necessarily be able to improve their performance.

The results of interviews with several respondents stated that not all job satisfaction can be obtained from the value of the material alone, but rather the pleasure mood of a comfortable atmosphere at work is more expected by employees. In job satisfaction there are social factors associated with social interaction between employees and employees with superiors. In the findings in the field this social factor is not so apparent in the Dira park ambulu, it is seen from the gap factor between superiors and subordinates in the company's organizational structure. The director of Dira park ambulu rarely seems to want to blend in with his subordinates, employees can only interact with other employees while working. So in this case even though the financial aspects of employees are met it is not certain that it can improve employee performance in Dirulu Park Ambulu. 
These results reject the findings of research conducted by nurcahyani (2016) which states that job satisfaction affects employee performance. This result also rejects the theory proposed by Wibowo, (2013) which states that job satisfaction as thoughts, feelings and the tendency of one's actions which constitute one's attitude towards work, employees who have job satisfaction tend to improve their performance. These results also reject the findings of research conducted by Fatima (2017) which states that job satisfaction affects employee performance.

\section{CONCLUSION}

The results of this study concluded that leadership influences job satisfaction. This means that the better leadership is carried out, the more it will increase employee job satisfaction. The results of this study also show that leadership influences employee performance. This means that the better the leadership, the better the performance of the employees of Dira park Ambulu Jember. In addition, the results of this study stated that job satisfaction does not affect employee performance. This means that job satisfaction obtained by employees does not necessarily improve employee performance. In this study also explained that the variable job satisfaction cannot mediate the effect of the relationship between leadership on the employee performance of Dira park Ambulu Jember.

\section{IMPLICATION}

Based on the results of the study stated that job satisfaction has no effect on employee performance, these results also state that job satisfaction cannot mediate the effect of the relationship between leadership on the employee performance of Dira park Ambulu Jember. For this reason, the management of Dira park Ambulu Jember should create better social relations with all employees. It aims to provide a comfortable and conducive atmosphere in the work environment so that there is no high work stress. Because not all employees who work expect high job returns, but they also need a good emotional relationship between employees and between employees and leaders. A good social relationship can create a conducive work atmosphere, so that in the end can improve employee performance and provide convenience in achieving company goals.

\section{REFERENCES}

Anke Priyono, F. M. (2012). Pengaruh Gaya Kepemimpinan Terhadap Kepuasan Kerja Dan Komitmen Manajemen Pada Laboratorium Mawar. Journal of Business and Banking, 2(1), 113. https://doi.org/10.14414/jbb.v2i1.436

Depitra, P. S., \& Soegoto, H. (2018). Pengaruh Gaya Kepemimpinan Terhadap Kinerja Karyawan. Majalah Ilmiah UNIKOM, 16(2), 185-188. https://doi.org/10.34010/miu.v16i2.13 61

Ferdinand, A. (n.d.). Metode Penelitian Manajemen [Out of Print].

Gusti, A. K. D., \& Adnyani, I. G. A. D. (2018). Pengaruh Gaya Kepemimpinan, Pemberdayaan Karyawan Dan Dukungan Organisasi Terhadap Kepuasan Kerja Karyawan. E-Jurnal Manajemen Unud, 7(7), 3594-3622. Retrieved from https://doi.org/10.24843/EJMUNUD.2 018.v7.i07.p6

Jamaludin, A. (2017). Pengaruh Gaya Kepemimpinan terhadap Kinerja Karyawan pada PT.Kaho IndahCitra Garment Jakarta. JABE (Journal of Applied Business and Economic), 3(3), 161.

https://doi.org/10.30998/jabe.v3i3.176 7

Martha, Y., \& Simanungkalit, V. (2013). Pengaruh Gaya Kepemimpinan Terhadap Kepuasaan Kerja Karyawan 
pada PT. LMA. UG Jurnal, Vol. 7(No. 06), 30-33. PENGARUH

GAYA

KEPEMIMPINAN

KINERJA

TERHADAP

PERCETAKAN DIMAS KOTA

PALEMBANG Mohd.Kurniawan DP

1. Jurnal Ilmiah Manajemen Bisnis Dan Terapan, (1), 33-48.

Prasetya, P. W. Y., \& Dewi, I. G. A. M. (2019). Pengaruh

Gaya

Kepemimpinan Transformasional

Terhadap Intention To Quit Dimediasi

Oleh Kepuasan Kerja Pada Karyawan.
E-Jurnal Manajemen Universitas

Udayana, $\quad 8(4), \quad 2042$.

https://doi.org/10.24843/ejmunud.201

9.v08.i04.p06

Rusady, K. P., \& Suprayitno. (2011). Pengaruh Kepemimpinan Terhadap Kinerja Pegawai Melalui Motivasi Sebagai Variabel Mediasi. Jurnal Manajemen Sumberdaya Manusia, 5(2), 171-181.

Sugiyono. (2011). Statistika untuk penelitian. Bandung: Alfabeta.

Sugiyono, P. D. (2014). Populasi dan sampel. Metode Penelitian Kuantitatif, Kualitatif Dan R\&D, (April 1952), 80. 